\title{
The International Community Role and NATO Intervention in Kosovo-Kumanovo Agreement
}

\author{
Phd. Isak Sherifi
}

Doi:10.5901/mjss.2014.v5n6p359

\begin{abstract}
After the failure of the Rambouillet conference following the intervention of the 19 most developed countries against Serbian targets thus paving the path establishing NATO troops in Kosovo and the signing of the military-technical agreement in Kumanovo which marked the end of the NATO bombing and the withdrawal of Serbian forces from the territory of Kosovo. The end of the war in Kosovo in 1999 opened a new chapter together with the international community based on Resolution 1244 in which Kosovo came under International protectorate. Priority will be given to safety, standards and status, while the benchmark was the Provisional Administrative Council and UNMIK who started the Kosovo state-building approach. As the foundation in 2001 will be prepared Constitutional Framework of Kosovo and as a result will begin the formation of local institutions under the supervision of the European and the international community.
\end{abstract}

Keywords: NATO, Rambouillet conference, Kosovo, Serbia, Kumanovo agreement.

\section{NATO Intervention in Kosovo-Kumanovo Agreement}

After the failure of the Rambouillet Conference, NATO intensive preparations began, for the start of military action against Serbia, according to the prepared plan and approved earlier by NATO. These air strikes began on 24 March 1999 and lasted 78 days these strikes resulted with the victory of NATO and the capitulation of Serbia (Bajrami 2002).

Compared with the beginning of the bombing of Serbian targets by NATO, Milosevic warranted his forces in Kosovo to begin a campaign of terror, which for a short period exceeded and also finished quickly like the ethnic cleansing he head in Eastern and Northern Bosnia during 1992.

Joint KLA and NATO war resulted in the liberation of the territory of Kosovo and complete removal of the military and paramilitary police and the removal of Kosovo's violent civil administration of Serbia.

The beginning of NATO bombing against Serbia, opened the debate about the legality, the causes and scope of the war, the effectiveness of the NATO campaign, as well as other issues related to the promotion of a new military doctrine and the creation of new international rule. These debates and controversy stemmed in fact, that this was the first military action undertaken by NATO in its Fifty year old history without formal mandate of the Security Council of the UN against a sovereign state, and its dimensions were much larger than those undertaken in Bosnia, which led to the end of the war and the achievement of the Dayton Agreement in 1995 (Bajrami 2002).

NATO launched its air campaign in order to prevent a humanitarian catastrophe, killings and expulsion of Kosovo Albanians and maintain regional security by imposing Belgrade peace plan for Kosovo in Rambouillet. However, the immediate of airstrikes effects were dissonant, they accelerated the operations of ethnic cleansing by Serb forces, the result of which was the removal and penetration of about 1 million Kosovo Albanians in Albania, the former Yugoslav Republic of Macedonia, in Montenegro and in many European countries. Deportation of refugees and their inflow increased the potential risk of social instability in the host countries, a fact that made NATO to commit its resources to humanitarian operations. The beginning of NATO bombing and the liberation war of KLA, influenced in Serbia to face with the loss of the war, to begin with punitive actions against civilians and massacred hundreds of civilians, women, children and elderly and exerting an unprecedented genocide since the end of World War II. With the start of the NATO bombing, Serbia began implementing the plan previously prepared in its quasi scientific circles - ethnic cleansing in Kosovo, one of the most dreadful crimes against humanity that were committed during this century, comparable by nature, though not by number , with the Jewish Holocaust carried out by Hitler.

On the other hand, the leadership of Milosevic began the war with the hope that the unity of the 19 member countries of NATO will seriously impeded if losses and NATO bombing would cause large numbers of civilian casualties. Although NATO unity passed a difficult test and therefore there was no stopping or reduction of the intensity of air strikes. Instead, NATO started the deployment of ground forces in the region before Belgrade accepted a deal, and this caused that conflict lasted 11 weeks, destroying a part of Serbian military and civilian targets in Kosovo and Serbia and caused a 
large number of civilian casualties. NATO attack has had a high moral motive. This motif was based on stopping the ethnic cleansing in Europe on the eve of the twenty century and stopped a deep humanitarian catastrophe. NATO stood up in defense of the principles of human rights, which have advantages in relation to the sovereignty of states. Exactly, this makes it legitimate to attack the Yugoslav Federation, even without a UN mandate. Despite the legitimacy of NATO's action against Serbia, its action was facing criticism from different directions. Some said that NATO should not act as international policeman, intervening without the clear mandate of the United Nations against a sovereign state. On the other hand, a large number of international law experts defended the legality of the intervention, in order to prevent the humanitarian catastrophe and saving people's lives. Legal basis according to these experts is defined in chapter VII of the UN Charter. After the fall of communism in Europe is quite prevalent concept that one of the primary functions is protection and not persecution of citizens and everyone who lives within their border. This new doctrine is consistent with the tendency of creating a new international order and the theory of limited sovereignty state started to promote that the Kosovo conflict can be a preventive for other ethnic conflicts.

Besides the NATO bombing, the KLA managed to counter Serbian attacks and defend civilian population in Kosovo that stayed there. For much more, KLA caused a lot of loss to the enemy and aided by NATO airstrikes won many battles and relieved some territories.

However, Serb forces killed and massacred over 10,000 Albanian civilians, burned over 100,000 houses destroyed and looted Albanian property and have taken as hostages and war prisoners a large number of Albanians, whose fate is unknown even to this day. Faced with NATO airstrikes and KLA liberation war, Serbia took brutal reprisals against an Albanian civilian population in which flagrantly violated the Geneva Convention, which defines the rights of war. Faced with certain defeat of the war, Serbia accepted its capitulation and signed the military-technical agreement so-called Kumanovo Agreement, which defined the technical details and the withdrawal of Serbian military and police and security forces from Kosovo and deployment of international security forces (KFOR) in Kosovo.

\section{Kumanovo Agreement}

Signing of the military and technical Agreement between Yugoslav Army and NATO, which represented the General Mike Jackson, marked the end of NATO bombing and the acceptance of the conditions that were submitted to Serbia, for recognition of capitulation and withdrawal of its forces from the territory of Kosovo. Upon reaching this agreement, political parties and the Kosovo Albanian military forces were not consulted.

This Agreement sets out the military-technical modality of Serbian forces withdrawal from the territory of Kosovo, the withdrawal dynamics and the entry of international security forces.

The agreement contains a total of six sections and two appendices. ${ }^{1}$

In the first section of the main obligations are defined, in which the Serbian side agreed to establish civil presence of the United Nations in Kosovo, and its acceptance by the establishment of the International Security Force ( KFOR ) (Dosja K" 1989-1999 Prishtinë pg. 51).

Further, in this agreement, Serbia accepts the withdrawal of all its security forces, including all the personnel and military organizations of the FRY and Republic of Serbia from the territory of Kosovo. In pursuance of this Article, the Air Safety Zone, including an area of 25 kilometers that extends beyond regional borders of Kosovo. Ground Safety Zone is defined as 5 -kilometer area, which extends beyond regional borders of Kosovo.

This part of the Agreement defines two main obligations arising from the agreement:

a. To place permanent military action prohibitions, under no circumstances any federal force should not enter inside or remain to the territory of Kosovo or the Ground Safety Zone and the Air Safety Zone, without prior consent of International Security Force Command ( KFOR );

b. To ensure support and authorization of the International Security Force (KFOR) and in particular to authorize KFOR to take such actions as are required, including the use of force if it's necessary, to ensure support of this agreement and International Protection Security Force (KFOR) and contribute to the secure environment of the international civil presence .

In Article 2 of the Agreement are defined obligations of the immediate cessation of military actions and conditions, the routes and dynamics of the Serbian and Yugoslav forces from the territory of Kosovo and create a safety air and ground area. Besides the withdrawal from Kosovo, Serbian and Yugoslav forces are forced to mark and clear all minefields in all lines of communication. Further in this article are exactly specified the withdrawal deadline of Serb forces from Kosovo.

${ }^{1}$ Dr. Bajrami Arsim: "vepër e cituar", faq.79-80 
The provisions of sections $3,4,5$ and 6 have technical character and refer to the implementation mechanisms of the agreement.

The signing of the agreement enables deployment action of the International Security Force in Kosovo ( KFOR) and the departure of Serb forces from Kosovo (Bajrami 2002). This fact creates the conditions for the return of Kosovo refugees in their land, which was done quickly, that shocked the international community.

After the entry of NATO forces in Kosovo, the Security Council on 10 June 1999 , adopted Resolution 1244 , which formally placed Kosovo under UN administration and paved the way for the deployment of international civilian and military presence in the territory of Kosovo.

\section{Years of International Administration in Kosovo}

On 18 November 2001, Rugova declared victory in the general elections held in Kosovo, but the foreign ministers of the European Union rejected the call to recognize the independence of Kosovo. On February 28, 2002, the parties agreed that Ibrahim Rugova to be as president of Kosovo, while former KLA fighter, Bajram Rexhepi was appointed as a prime minister. In December 2003, the United Nations unfolded the way they should follow Kosovo to meet democratic standards to achieve the final status. In 2004, Belgrade demanded Kosovo to have only extended autonomy and Serbs boycotted general elections that year. After these elections, as prime minister was proclaimed a former KLA fighter, Haradinaj, and chief administrator of Kosovo, Soren Jessen Petersen, said to the European Union in February 2005 that talks on Kosovo's final status could begin in September or October 2005, if the UN would assess that the appropriate standards were achieved democratically.

In November 2005 officially begin the process for setting the final status of Kosovo (Gazeta "Koha" Shkup $2007 \mathrm{fq}$. 17).

Kosovo since 1999, after Serbian forces were forced to leave Kosovo has been administered by the mission of the United Nations UNMIK and Kosovo's democratic institutions: Parliament, President and Government of Kosovo. Although Serbia has no control over Kosovo, in 1244 the Security Council Resolution, for several times is mentioned that Kosovo is under UN protectorate but legally part of the Federal Republic of Yugoslavia. Under this resolution the UN has responsibility for civil administration and NATO for security in Kosovo. It is said that Kosovo friendly states in 1999 didn't want to include the word Yugoslavia in the resolution, but Russia had the right of veto in the Security Council and insisted.

On 2 February 2007 the special envoy for Kosovo status, Martti Ahtisaari, presented his proposal in Pristina and Belgrade. Kosovo citizens and foreigners are of the opinion that this will lead to the creation of the independent state of Kosovo. Envoys from the U.S. EU and Russia launched extra 120 daily negotiations between Kosovo and Serbia in an attempt to reach an agreement. The trio presents the final report of the UN Secretary General. On 16 February the Council of the European Union established the EULEX mission to Kosovo and broad scope of the rule of law. On 17 February 2008 Kosovo declares independence. (Mark 2009)

\section{References}

Reuter Jens; "Shqiptarët në Jugosllavi" Tiranë 2003

Bajrami Arsim: "E drejta e Kosovës në tranzicion", Prishtinë, 2002

Tepshi Qazim; "Kosova dhe diplomacia imponuese" ;Toena, Tiranë 1999

Buja Ramë; "Konferenca e Rambujesë (aspekti juridik, politik e ndërkombëtarë), Prishtinë 2004

Krasniqi Jakup; "Kthesa e madhe" Prishtinë 2006

Revista ekskluzive "Dosja K" 1989-1999 Prishtinë

Gazeta 'Koha" Shkup, 2007

Weller Mark; " Shtetësia e kontestuar" Prishtinë 2009 
